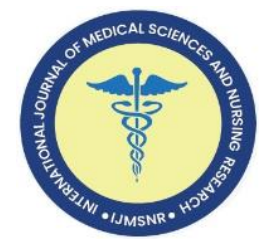

\title{
A study of modifiable and non-modifiable risk factors associated with of diabetic nephropathy - A preliminary observational study in Eastern Odisha, India
}

\author{
Suchanda Sahu ${ }^{1}$ (D), Manish Taywade ${ }^{2}$, Sujata Devi ${ }^{3}$, Saurav Nayak ${ }^{4}$, Dipti Sudha $M^{5}$
}

${ }^{1}$ Associate Professor, Department of Biochemistry, ${ }^{2}$ Assistant Professor, Department of Community Medicine and Family Medicine, ${ }^{3}$ Assistant Professor, Department of Medicine, ${ }^{4}$ Second year Junior Resident, Department of Biochemistry, ${ }^{5}$ First year Junior Resident, Department of Biochemistry, All India Institute of Medical Sciences, Bhubaneswar, India

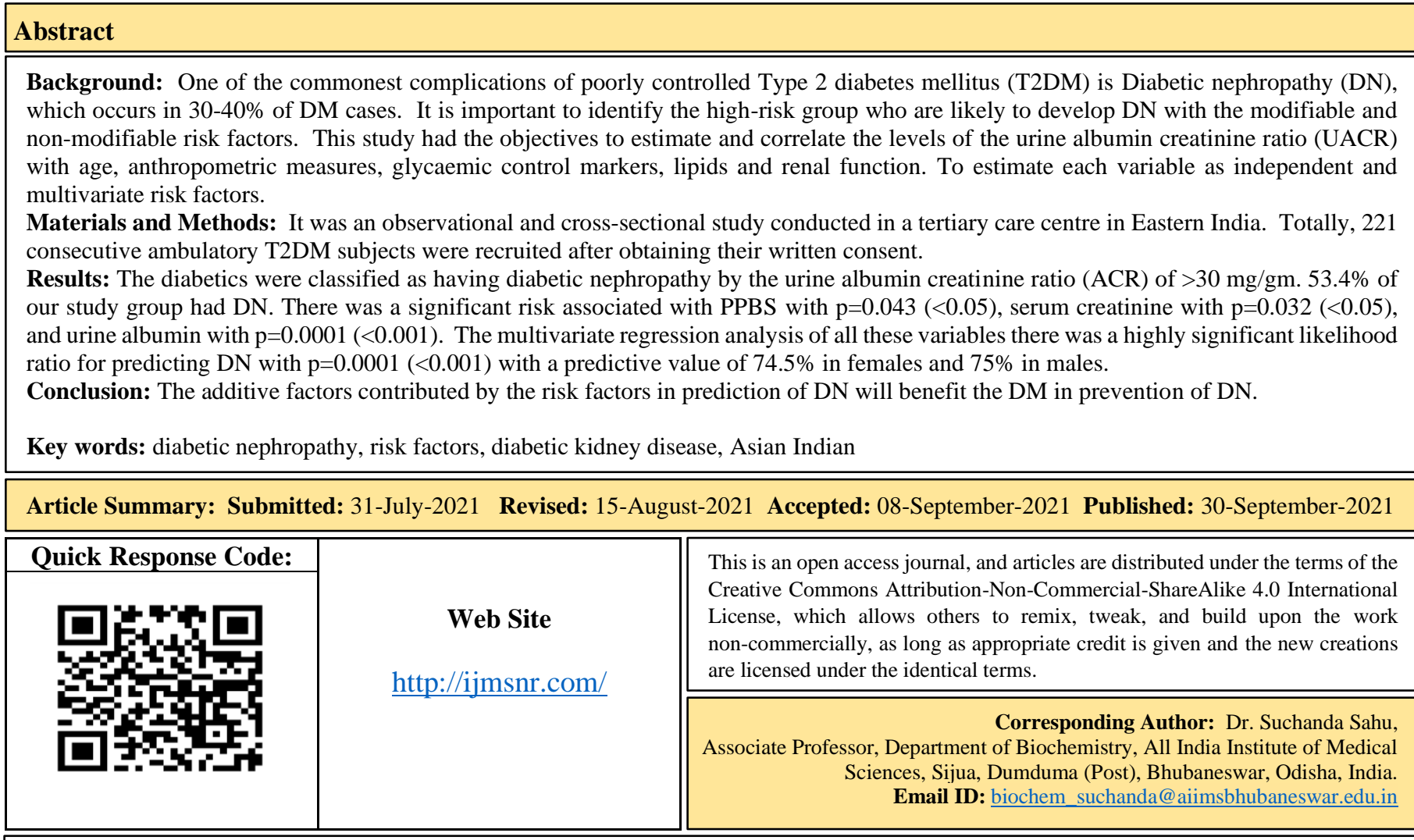

\section{Introduction}

Diabetic nephropathy (DN) affects approximately $40 \%$ of the type 2 diabetes mellitus (T2DM) patients. [1] DN is diagnosed by the presence of albumin in urine. They are classified as microalbuminuria and macroalbuminuria with urine albumin: creatinine ratio of $30-300 \mathrm{mg} / \mathrm{gm}$ in the former and $>300 \mathrm{mg} / \mathrm{gm}$ in the latter. Microalbuminuria stage of renal involvement was termed as incipient nephropathy which may already be present in T2DM at the time of diagnosis. [2] Progression of normo-albuminuria to micro and macroalbuminuria can occur silently and faster with associated risk factors like dyslipidaemia, smoking habit, hypertension and poor glycaemic control. [3] In the South-Asian population, there is an increased predisposition to DN irrespective of the central obesity, [4] hence the need to point causal factors to body fat distribution initiating insulin resistance and inflammation. In routine management of diabetic patients, their blood and urine tests are done annually to monitor the disease control and to screen for DN. Microalbuminuria is also associated with increased risk for cardiovascular diseases and death. [1] Hence, it is imperative to adopt strategies for preventing the development of microalbuminuria and in delaying the progression to advanced stages of $\mathrm{DN}$. That can be achieved by good glycaemic control by maintaining glycated haemoglobin $\left(\mathrm{HbA} \mathrm{C}_{1}\right)$ at $7 \%$, treating comorbidities like hypertension and dyslipidaemia.

Though microalbuminuria is the gold standard for screening and detection of DN, its determination in clinical laboratories are inconsistent because of the immunoassay techniques used [5,6]. In diabetics, the albumin in urine can be modified by non- enzymatic glycation and

How to cite this article: Sahu S, Taywade M, Devi S, Nayak S, Sudha DM. A study of modifiable and non-modifiable risk factors associated with of diabetic nephropathy - A preliminary observational study in Eastern Odisha, India. Int J Med Sci and Nurs Res 2021;1(1):17-21 
hydrolysis during its passage in the renal tubules. These modifications can underestimate the albumin by the antibodies used for assay $[7,8]$, thereby delay the detection of DN and its treatment. In this study we assessed the correlation of ACR with non-modifiable risk factors like age and gender of patient and with modifiable risk factors like body mass index (BMI), waist hip ratio (WHR), atherogenic index (AI) calculated from fasting blood lipid levels and $\mathrm{HbA}_{1} \mathrm{C}$.

\section{Material and Methods:}

It was a cross-sectional comparative study on 221 ambulatory T2DM subjects conducted in a tertiary care centre in Eastern India after the approval of the Institutional Ethical Committee (IEC- T/IMF/18-19/32). The cases were from our Non - Communicable Diseases (NCD) Outpatients clinic (OPD), All India Institute of Medical Sciences, Bhubaneswar, India, who attended for routine follow-up clinic during the month of March 2020. Convenient sampling was done due to the COVID19 pandemic. Their clinical and anthropometric data were noted after obtaining their written consent. $5 \mathrm{ml}$ of blood in fasting state and $10 \mathrm{ml}$ of midstream spot urine was collected in different vacutainers and urine vials for estimation of the following: serum creatinine, glycated haemoglobin fasting (FBS) and post prandial blood sugar (PPBS), urine creatinine and albumin. The lipid profile included total cholesterol (TC), triglycerides (TG), high density lipoprotein (HDL) and low-density lipoproteins (LDL). All the estimations were done the same day using the Beckman Coulter Chemistry Analyzer AU5800 (Beckman Coulter, Brea, USA).

The calculated parameters were body mass index (BMI), waist hip ratio (WHR), atherogenic index of plasma (AIP) [9], urinary albumin: creatinine ratio (UACR) and estimated glomerular filtration rate (eGFR). [10] The statistical analysis was done to compare the diabetics with and without DN. The comparison was done by Mann Whitney U test.

The relative risk estimates were calculated and the correlation was estimated for the independent variables by Spearman's correlation as the data were not normally distributed which was seen by the KolmogorovSmirnov test. The comparisons between gender groups and those with and without DN were by Kruskal Wallis Test and post hoc test by Tukey's test. The multivariate regression was estimated for the independent variables. All these were done using SPSS 19.0 version [IBM, Armonk, NY, USA]. p-value $<0.05$ was considered as statistically significant.

\section{Results:}

Clinical characteristics: There were 221 diabetic patients who consented to participate in the study. There were 143 males and 78 females. Table1 shows the general clinical characteristics of the study participants. Considering the anthropometric cut-off levels for Asian Indians, 72.4\% were overweight and obese; $94.4 \%$ of males and $98.7 \%$ females had high WHR. $79.1 \%$ had poor glycaemic control as seen by $\mathrm{HbA}_{1} \mathrm{C}$ and $90.9 \%$ had a high-risk dyslipidaemia as seen by the AIP. Though $53.4 \%$ of our study group had DN, a larger proportion of the total that is $72.8 \%$ had decreased eGFR. The study participants were classified as having diabetic nephropathy by the UACR.

Table 1: Distribution of general characteristics of the study population $(\mathrm{N}=221)$

\begin{tabular}{|l|l|c|c|}
\hline \multicolumn{2}{|c|}{ Covariates } & $\begin{array}{c}\text { No. of } \\
\text { Patients }\end{array}$ & Percentage \\
\hline \multirow{3}{*}{ Age (in years) } & $<60$ & 172 & 77.8 \\
\cline { 2 - 4 } & $\geq 60$ & 49 & 22.2 \\
\hline \multirow{3}{*}{ Gender } & Male & 143 & 64.7 \\
\cline { 2 - 4 } & Female & 78 & 35.3 \\
\hline \multirow{3}{*}{ BMI } & $<23$ & 61 & 27.6 \\
\cline { 2 - 4 } & $\geq 23$ & 160 & 72.4 \\
\hline \multirow{5}{*}{ WHR } & $\mathrm{M},<0.90$ & 8 & 5.6 \\
\cline { 2 - 4 } & $\mathrm{M} \geq 0.90$ & 135 & 94.4 \\
\cline { 2 - 4 } & $\mathrm{F}<0.80$ & 1 & 1.3 \\
\cline { 2 - 4 } & $\mathrm{F} \geq 0.80$ & 77 & 98.7 \\
\hline \multirow{3}{*}{ HbA C } & $<7.0 \%$ & 46 & 20.8 \\
\cline { 2 - 4 } & $\geq 7.0 \%$ & 175 & 79.1 \\
\hline \multirow{3}{*}{ AIP } & $<0.24$ & 20 & 9.1 \\
\cline { 2 - 4 } & $\geq 0.24$ & 201 & 90.9 \\
\hline ACR & $<30 \mathrm{mg} / \mathrm{gm}$ & 94 & 42.5 \\
\cline { 2 - 4 } & $\geq 30 \mathrm{mg} / \mathrm{gm}$ & 127 & 57.5 \\
\hline \multirow{3}{*}{ eGFR } & $>90 \mathrm{ml} / \mathrm{min}$ & 60 & 27.2 \\
\cline { 2 - 4 } & $<90 \mathrm{ml} / \mathrm{min}$ & 161 & 72.8 \\
\hline DN & $\mathrm{Absent}$ & 103 & 46.6 \\
\cline { 2 - 4 } & Present & 118 & 53.4 \\
\hline
\end{tabular}

The comparison of the two groups by Mann Whitney $U$ test. There was a significant difference in PPBS $(\mathrm{p}=0.013), \mathrm{HbA}_{1} \mathrm{C}(\mathrm{p}=0.041)$ and UACR $(\mathrm{p}<0.001)$. There was no significant difference in the age, gender, BMI, WHR, FBS, lipid profile, AIP, serum creatinine and eGFR between the groups as shown in Table-2.

\section{Association of risk factors with DN:}

The risk estimate calculated using the cut off values for each variable relevant to our population and as per gender wherever applicable. Though there was a 10-20\% increased risk for age $>60$ years, male gender, BMI, WHR, FBS, $\mathrm{HbA}_{1} \mathrm{C}$, AIP and LDL among the serum lipids and a $20 \%$ decrease in HDL had increased risk of DN, none were statistically significant as shown in Table-3.

This may be because of the consecutive convenient sampling of one month evaluated as a preliminary study here. There was a significant risk associated with PPBS $(\mathrm{p}=0.043)$, serum creatinine $(\mathrm{p}=0.032)$, and urine albumin $(\mathrm{p}=0.0001)$. 
Table 2: Differences Between Diabetic Nephropathy Group for Various Risk Factors

\begin{tabular}{|c|c|c|c|c|}
\hline \multirow{2}{*}{\multicolumn{2}{|c|}{ Parameters }} & \multicolumn{2}{|c|}{ Diabetic Nephropathy } & \multirow{2}{*}{$\begin{array}{c}\mathrm{p} \\
\text { value }\end{array}$} \\
\hline & & $\begin{array}{l}\text { Absent } \\
(\mathrm{n}=94)\end{array}$ & $\begin{array}{l}\text { Present } \\
(\mathrm{n}=127)\end{array}$ & \\
\hline \multicolumn{2}{|c|}{ Age } & $52(43-60)$ & $50(43-58)$ & 0.636 \\
\hline \multirow{2}{*}{ Sex } & Male & $62(65.96 \%)$ & $76(59.84 \%)$ & \multirow{2}{*}{0.353} \\
\hline & Female & $32(34.04 \%)$ & $51(40.16 \%)$ & \\
\hline \multicolumn{2}{|c|}{$\mathrm{BMI}\left(\mathrm{kg} / \mathrm{m}^{2}\right)$} & $\begin{array}{c}25.30 \\
(23.46-27.69)\end{array}$ & $\begin{array}{c}25.34 \\
(22.22-28.06)\end{array}$ & 0.434 \\
\hline \multicolumn{2}{|c|}{ WHR } & $0.948(0.91-0.99)$ & $0.946(0.91-0.98)$ & 0.439 \\
\hline \multicolumn{2}{|c|}{ FBS (mg/dl) } & $141.5(121-179)$ & $152(122-221)$ & 0.187 \\
\hline \multicolumn{2}{|c|}{ PPBS (mg/dl) } & $208.5(185-290)$ & $245(189-321)$ & 0.013 \\
\hline \multicolumn{2}{|c|}{$\mathrm{HbA}_{1} \mathrm{C}(\%)$} & $7.875(7.08-8.8)$ & $8.3(7.2-10.3)$ & 0.041 \\
\hline \multicolumn{2}{|c|}{$\begin{array}{l}\text { S. Creatinine } \\
(\mathrm{mg} / \mathrm{dl})\end{array}$} & $1(0.8-1.1)$ & $1(0.8-1.2)$ & 0.393 \\
\hline \multicolumn{2}{|c|}{$\begin{array}{l}\text { eGFR } \\
(\mathrm{ml} / \mathrm{min})\end{array}$} & $\begin{array}{c}82.53 \\
(66.67-94.31) \\
\end{array}$ & $\begin{array}{c}74.77 \\
(64.94-91.08) \\
\end{array}$ & 0.142 \\
\hline \multicolumn{2}{|c|}{$\mathrm{TC}(\mathrm{mg} / \mathrm{dl})$} & $187(161-210)$ & $190(159-227)$ & 0.613 \\
\hline \multicolumn{2}{|c|}{ TG (mg/dl) } & $153(119-204)$ & $149(108-204)$ & 0.648 \\
\hline \multicolumn{2}{|c|}{ HDL (mg/dl) } & $44(38-51)$ & $46(39-53)$ & 0.160 \\
\hline \multicolumn{2}{|c|}{ LDL (mg/dl) } & $110(91-135)$ & $114(92-136)$ & 0.740 \\
\hline \multicolumn{2}{|c|}{ AIP } & $0.557(0.43-0.69)$ & $0.529(0.37-0.69)$ & 0.280 \\
\hline \multicolumn{2}{|c|}{$\begin{array}{l}\text { UACR } \\
\text { (mg/gm) }\end{array}$} & $\begin{array}{c}14.41 \\
(6.53-22.23)\end{array}$ & $\begin{array}{c}82.5 \\
(46.95-190.43)\end{array}$ & $<0.001$ \\
\hline
\end{tabular}

The Spearman's correlation (Table 4) of ACR with FBS, PPBS, $\mathrm{HbA}_{1} \mathrm{C}$ and $\mathrm{u}$. albumin were positive with $(\mathrm{p}=0.028,<0.001,0.001$ and $<0.001$ respectively) on overall estimation of all cases (not shown here). But on estimating the correlation in females, only PPBS correlated significantly and in males there was significant positive correlation with FBS, PPBS, $\mathrm{HbA}_{1} \mathrm{C}$, serum creatinine and spot urine albumin was negative with eGFR with $\mathrm{p}=0.028$. The other individual independent factors like age, BMI, WHR, serum lipids and AIP did not correlate significantly with ACR in both sexes. On doing a multivariate logistic regression analysis of all these variables [Table 5a and 5b] there was a significant likelihood ratio for predicting $\mathrm{DN}$ ( $\mathrm{p}=0.014$ and 0.001 in females and males respectively) with a substantial predictive value of $74.5 \%$ in females and $75 \%$ in males by Cox and Snell R square.

\section{Discussion:}

Diabetic nephropathy is a common complication of T2DM. It is usually detected in late stages from where it rapidly progresses to end stage renal disease (ESRD). Early detection, good glycaemic control and nephro-protective treatment can prevent ESRD. [11] Apart from this it is important to identify the subgroup among T2DM, likely to develop DN considering the modifiable risk factors like body fat, serum lipids, kidney function and glycaemic control. From our preliminary it is evident that there is a risk associated with biomarkers of glycaemic
Table 3: Risk Factors (Modifiable \& Non-Modifiable) for Diabetic Nephropathy

\begin{tabular}{|c|c|c|c|c|c|c|}
\hline \multirow{2}{*}{ Factors } & \multirow{2}{*}{ Parameters } & \multirow{2}{*}{ Classifications } & \multicolumn{2}{|c|}{$\begin{array}{c}\text { Diabetic } \\
\text { Nephropathy }\end{array}$} & \multirow{2}{*}{$\begin{array}{c}\text { Relative } \\
\text { Risk }\end{array}$} & \multirow{2}{*}{$\begin{array}{c}\mathbf{P} \\
\text { Value }\end{array}$} \\
\hline & & & Absent & Present & & \\
\hline \multirow{4}{*}{$\begin{array}{l}\text { Non - } \\
\text { Modifiable }\end{array}$} & \multirow{2}{*}{$\begin{array}{l}\text { Age (in } \\
\text { years) }\end{array}$} & $<60$ & 74 & 108 & \multirow{2}{*}{1.218} & \multirow{2}{*}{0.284} \\
\hline & & $\geq 60$ & 20 & 19 & & \\
\hline & \multirow{2}{*}{ Sex } & Male & 62 & 76 & \multirow{2}{*}{1.165} & \multirow{2}{*}{0.400} \\
\hline & & Female & 32 & 51 & & \\
\hline \multirow[t]{25}{*}{ Modifiable } & \multirow{2}{*}{$\begin{array}{l}\text { BMI } \\
\left(\mathrm{kg} / \mathrm{m}^{2}\right)\end{array}$} & $<23$ & 20 & 41 & \multirow{2}{*}{1.250} & \multirow{2}{*}{0.048} \\
\hline & & $\geq 23$ & 74 & 86 & & \\
\hline & \multirow{2}{*}{ WHR } & $\begin{array}{l}<0.9(\mathrm{M}) /<0.85 \\
(\mathrm{~F}\end{array}$ & 1 & 1 & \multirow{2}{*}{1.177} & \multirow{2}{*}{1.000} \\
\hline & & $\begin{array}{l}\geq 0.9(\mathrm{M}) / \\
\geq 0.85(\mathrm{~F})\end{array}$ & 93 & 126 & & \\
\hline & \multirow{2}{*}{$\begin{array}{l}\text { FBS } \\
(\mathrm{mg} / \mathrm{dl})\end{array}$} & $<110$ & 9 & 22 & \multirow{2}{*}{1.284} & \multirow{2}{*}{0.119} \\
\hline & & $\geq 110$ & 85 & 105 & & \\
\hline & \multirow{2}{*}{$\begin{array}{l}\text { PPBS } \\
(\mathrm{mg} / \mathrm{dl})\end{array}$} & $<140$ & 3 & 0 & \multirow{2}{*}{2.396} & \multirow{2}{*}{0.043} \\
\hline & & $\geq 140$ & 91 & 127 & & \\
\hline & \multirow{2}{*}{$\mathrm{HbA}_{1} \mathrm{C}(\%)$} & $<7$ & 23 & 23 & \multirow{2}{*}{1.232} & \multirow{2}{*}{0.315} \\
\hline & & $\geq 7$ & 71 & 104 & & \\
\hline & \multirow{2}{*}{$\begin{array}{l}\text { Serum } \\
\text { Creatinine } \\
(\mathrm{mg} / \mathrm{dl})\end{array}$} & $\begin{array}{l}\leq 1.2(\mathrm{M}) / \\
\leq 1.1(\mathrm{~F})\end{array}$ & 87 & 105 & 1.877 & 0.032 \\
\hline & & $>1.2(\mathrm{M}) />1.1(\mathrm{~F})$ & 7 & 22 & & \\
\hline & eGFR & $<90$ & 67 & 94 & $106 ?$ & 0650 \\
\hline & $(\mathrm{ml} / \mathrm{min})$ & $\geq 90$ & 27 & 33 & 1.002 & 0.650 \\
\hline & & $<200$ & 60 & 80 & 1021 & 1000 \\
\hline & $(\mathrm{mg} / \mathrm{dl})$ & $\geq 200$ & 34 & 47 & 1.021 & 1.000 \\
\hline & TG & $<150$ & 44 & 65 & 1077 & 0.587 \\
\hline & $(\mathrm{mg} / \mathrm{dl})$ & $\geq 150$ & 50 & 62 & 1.071 & 0.501 \\
\hline & HDL & $>35(\mathrm{M}) />39(\mathrm{~F})$ & 77 & 112 & 0767 & 0246 \\
\hline & $(\mathrm{mg} / \mathrm{dl})$ & $<35(\mathrm{M}) /<39(\mathrm{~F})$ & 17 & 15 & 0.101 & 0.240 \\
\hline & LDL & $<100$ & 36 & 42 & 138 & 0477 \\
\hline & $(\mathrm{mg} / \mathrm{dl})$ & $\geq 100$ & 58 & 85 & 1.150 & 0.411 \\
\hline & A IP & $\leq 0.24$ & 6 & 14 & 1245 & 0343 \\
\hline & НIII & $>0.24$ & 88 & 113 & $1.2+J$ & $0.54 J$ \\
\hline & $\begin{array}{l}\text { Urine } \\
\text { Albumin } \\
(\mathrm{mg} / \mathrm{L})\end{array}$ & $<30$ & 70 & 33 & 3.341 & 0.0001 \\
\hline
\end{tabular}

Bolded p-value $<0.05$ Statistically Significant

control (PPBS and $\mathrm{HbA}_{1} \mathrm{C}$ ), more so in males as compared to females. Similar results have been reported by authors in Asia [12] among Asians in Europe [4], and from heterogenous populations from 20 cohorts. [13] Though strict glycaemic control decreased the risk for DN b $40 \%$, it alone cannot prevent the initiation and progression of DN. [1] Majority of our patients were overweight or obese and had higher WHR than normal. Though BMI associated significantly as a risk factor for DN with UACR, WHR didn't. Neither of them was different in the two groups. There was no difference in gender as a risk factor for DN. However, studies among Asians have shown that women who have DN rapidly progress to ESRD as compared to their male counterparts. [14, 15] 
Sahu $\mathrm{S}$ et al., A study of modifiable and non-modifiable risk factors associated with of diabetic nephropathy

Table 4: Correlation of ACR with independent factors in the diabetics grouped according to gender $(\mathrm{N}=221)$

\begin{tabular}{|c|c|c|c|c|}
\hline \multirow{2}{*}{ Parameters } & \multicolumn{2}{|c|}{ Females } & \multicolumn{2}{c|}{ Males } \\
\cline { 2 - 5 } & Spearman's rho & $\begin{array}{c}\mathrm{p} \\
\text { value }\end{array}$ & Spearman's rho & $\begin{array}{c}\mathrm{p} \\
\text { value }\end{array}$ \\
\hline Age (years) & -0.137 & 0.228 & 0.032 & 0.703 \\
\hline BMI $\left(\mathrm{kg} / \mathrm{m}^{2}\right)$ & 0.05 & 0.661 & -0.095 & 0.262 \\
\hline WHR & 0.008 & 0.947 & -0.083 & 0.329 \\
\hline FBS (mg/dl) & 0.085 & 0.455 & $0.176^{*}$ & $\mathbf{0 . 0 3 6}$ \\
\hline PPBS (mg/dl) & $0.267^{*}$ & $\mathbf{0 . 0 1 7}$ & $0.213^{*}$ & $\mathbf{0 . 0 1 1}$ \\
\hline HbA C $(\%)$ & 0.161 & 0.156 & $0.248^{* *}$ & $\mathbf{0 . 0 0 3}$ \\
\hline $\begin{array}{c}\text { S. Creatinine } \\
(\mathrm{mg} / \mathrm{dl})\end{array}$ & 0.076 & 0.508 & $0.191^{*}$ & $\mathbf{0 . 0 2 2}$ \\
\hline eGFR (ml/min) & 0.043 & 0.705 & $-0.185^{*}$ & $\mathbf{0 . 0 2 8}$ \\
\hline TC (mg/dl) & 0.172 & 0.129 & -0.005 & 0.956 \\
\hline TG (mg/dl) & 0.060 & 0.601 & -0.070 & 0.406 \\
\hline HDL (mg/dl) & 0.111 & 0.332 & 0.030 & 0.724 \\
\hline LDL (mg/dl) & 0.176 & 0.120 & -0.011 & 0.901 \\
\hline AIP & -0.015 & 0.895 & -0.073 & 0.387 \\
\hline $\begin{array}{c}\text { U. Albumin } \\
\text { (mg/L) }\end{array}$ & $0.752^{* *}$ & $\mathbf{0 . 0 0 1}$ & $0.658^{* *}$ & $\mathbf{0 . 0 0 1}$ \\
\hline
\end{tabular}

** Correlation is significant $\mathbf{p}<0.01$; * Correlation is significant $p<0.05$

Table 5a: Multivariate Regression of the independent variables as risk factors for DN

\begin{tabular}{|c|c|c|c|c|c|}
\hline \multicolumn{6}{|c|}{ Model Fitting Information } \\
\hline \multirow{2}{*}{ Sex } & \multirow{2}{*}{ Model } & \multirow{2}{*}{$\begin{array}{c}\text { Model Fitting } \\
\text { Criteria }\end{array}$} & \multicolumn{2}{|c|}{$\begin{array}{c}\text { Likelihood Ratio } \\
\text { Tests }\end{array}$} & \multirow[b]{2}{*}{ Sig. } \\
\hline & & & $\begin{array}{l}\text { Chi- } \\
\text { Square }\end{array}$ & df & \\
\hline \multirow[t]{2}{*}{ Female } & $\begin{array}{l}\text { Intercept } \\
\text { Only }\end{array}$ & 107.981 & & & \\
\hline & Final & 0 & 107.981 & 78 & 0.014 \\
\hline \multirow[t]{2}{*}{ Male } & $\begin{array}{l}\text { Intercept } \\
\text { Only }\end{array}$ & 196.741 & & & \\
\hline & Final & 0 & 196.741 & 141 & 0.001 \\
\hline
\end{tabular}

Bolded p-value $<0.05$ Statistically Significant

Table 5b: Predictive value of the multivariate analysis

\begin{tabular}{|l|l|c|}
\hline \multicolumn{2}{|l|}{ Pseudo R-Square } & \\
\hline Female & Cox and Snell & 0.745 \\
\hline & Nagelkerke & 1 \\
\hline Male & McFadden & 1 \\
\hline & Cox and Snell & 0.75 \\
\hline & Nagelkerke & 1 \\
\hline & McFadden & 1 \\
\hline
\end{tabular}

The baseline eGFR and kidney function are important factors in DN risk and progression. [1] In our study though eGFR was not significantly different in the two groups; with and without DN, serum creatinine levels were a risk in both sexes and eGFR negatively correlated with UACR in males as shown in Table-4. As eGFR is closely related to age, baseline eGFR at the time of diagnosis of T2DM and further monitoring to see the rate of decline [16] is imperative for initiating treatment with antidiabetic agents which will protect the kidneys also. [12]

In our study, the serum lipids were not statistically different in the two groups, yet studies have shown that HDL and TG are independent risk factors for cardiovascular disease, systolic blood pressure (SBP) being the measure. [13] As we have not considered the treatment naïve T2DM patients and we have not taken in account the drug history of each participant, our statement for or against the association of serum lipids in DN will not be exact.

As T2DM involves multiple organs and its complications can coexist to varying degrees in individuals, multiple factors affect the course of the disease. The multivariate regression analysis showed significant predictive value of the risk factors considered in our study. Studies on identification of risk factors have identified similar factors and others like SBP, duration of disease, rate of decline in eGFR, age and presence of diabetic retinopathy. [3, 12]

The strength of our study is that, though it is a preliminary study conducted during the lockdown for pandemic, the conjoined effect of the modifiable and non-modifiable risk factors showed substantial predictive value. Our study is limited by the sample number and the lack of drug history such as lipid lowering agents, antihypertensives, insulin or oral hypoglycaemic agents.

\section{Conclusion:}

In conclusion, the findings of our study have implications in the clinical scenario of diabetes. As the disease, T2DM is not only about current glycaemic control, but involves constant clinical and lab monitoring to evade complications. Patient education about disease and empowering them with the knowledge and ability is more important that medications alone. An overall change in diet, physical activity, and other lifestyle modifications should benefit each patient. Larger cohort studies are suggested to understand the additive effects of risk factors.

Acknowledgment: We acknowledge the consent and cooperation of our study participants and the help of other department staff and colleagues.

Authors' Contributions: SS, MT and SDM conceived the study design and initial draft of the manuscript. SD, SN and DSM collected clinical data. SS and SN analysed the data. All the authors edited and approved of the final draft of the manuscript.

Here, SS - Suchanda Sahu, MT - Manish Taywade, SD - Sujata Devi, SN - Saurav Nayak and, Dipti Sudha M - DSM 
Source of funding: This study was done as intramural research grant for Faculty from my Institute; All India Institute of Medical Sciences (AIIMS), Bhubaneswar, India.

Conflict of Interest: The authors declare that there was no conflict of interest.

\section{References:}

1. Gross JL, de Azevedo MJ, Silveiro SP, Canani LH, Caramori ML, Zelmanovitz T. Diabetic Nephropathy: Diagnosis, Prevention, and Treatment. Diabetes Care 2005;28(1):164-176. Available from: http://care.diabetesjournals.org/cgi/doi/10.2337/diacare.28.1.16 4

2. Van JAD, Scholey JW, Konvalinka A. Insights into Diabetic Kidney Disease Using Urinary Proteomics and Bioinformatics. Journal of the American Society of Nephrology 2017;28(4):1050-1061.

DOI: http://doi/10.1681/ASN.2016091018

3. Viswanathan V, Tilak P, Kumpatla S. Risk factors associated with the development of overt nephropathy in type 2 diabetes patients: A 12 years observational study. Indian Journal of Medical Research 2012;136:46-53.

4. Chandie Shaw PK, Baboe F, van Es LA, van der Vijver JC, van de Ree MA, de Jonge N, et al. South-Asian type 2 diabetic patients have higher incidence and faster progression of renal disease compared with Dutch-European diabetic patients. Diabetes Care 2006;29(6):1383-1385.

5. Greive KA, Eppel GA, Reeve S, Smith AI, Jerums G, Comper WD. Immuno-unreactive albumin excretion increases in streptozotoin diabetic rats. AM J Kidney Dis 2001;38:144-152. PMID: 11431194

6. Qsicka TM, Comper WD. Characterization of Immunochemically Non-reactive urinary albumin. Clin Chem 2004;50(12):2286-2291. PMID: 15388637

7. Burne MJ, Panagiotopoulus S, Jerums G, Comper WD. Alterations in the renal degradation of albumin in early experimental diabetes in the rat: a new factor in the mechanism of albuminuria. Clin Sci (Lond) 1998;95(1):67-72. PMID: 9662487

8. Qsicka TM, Honlihas CA, Chan JG, Jerums G, Comper WD. Albuminuria in patients with type 1 diabetes is directly linked to changes in the lysosome-mediated degradation of albumin during renal passage. Diabetes 2000;49:1579-1584. PMID: 10969843

9. Dobiásová M, Frohlich J. The plasma parameter log (TG/HDLC) as an atherogenic index: correlation with lipoprotein particle size and esterification rate in apoB-lipoprotein-depleted plasma (FER(HDL)). Clin Biochem 2001;34(7):583-588. PMID: 11738396
10. Cockcroft DW, Gault MH. Prediction of creatinine clearance from serum creatinine. Nephron 1976;16(1):31-41. PMID: 1244564

11. Żyłka A, Dumnicka P, Kuśnierz-Cabala B, Gala-Błądzińska A, Ceranowicz P, Kucharz J, et al. Markers of Glomerular and Tubular Damage in the Early Stage of Kidney Disease in Type 2 Diabetic Patients. Mediators Inflamm 2018;2018:7659243. DOI: https://doi.org/10.1155/2018/7659243

12. Huang CH, Chen CP, Huang YY, Hsu BRS. Modifiable factors related to 7-year renal outcomes in subjects with type 2 diabetes and chronic kidney disease stage 3. J Postgrad Med 2020;66(4):187-193.

13. Jiang W, Wang J, Shen X, Lu W, Wang Y, Li W, et al. Establishment and Validation of a Risk Prediction Model for Early Diabetic Kidney Disease Based on a Systematic Review and Meta-Analysis of 20 Cohorts. Diabetes Care. 2020;43(4):925-933. PMID: 32198286

14. Shen Y, Cai R, Sun J, Dong X, Huang R, Tian S, et al. Diabetes mellitus as a risk factor for incident chronic kidney disease and end-stage renal disease in women compared with men: a systematic review and meta-analysis. Endocrine 2017;55(1):66-76. PMID: 27477292

15. Liu J-J, Liu S, Choo RWM, Wee SL, Xu A, Lim SC. Sex modulates the association of fibroblast growth factor 21 with end-stage renal disease in Asian people with Type 2 diabetes: a 6.3-year prospective cohort study. Diabet Med 2018;35(7):880 886. PMID: 29653030

16. Kerschbaum J, Rudnicki M, Dzien A, Dzien-Bischinger C, Winner H, Heerspink HL, et al. Intra-individual variability of eGFR trajectories in early diabetic kidney disease and lack of performance of prognostic biomarkers. Sci Rep 2020;10(1):19743. DOI: https://doi.org.10.1038/s41598-020$\underline{76773-0}$

Publish your research articles with International Journal of Medical Sciences and Nursing Research Website: http://ijmsnr.com/ 